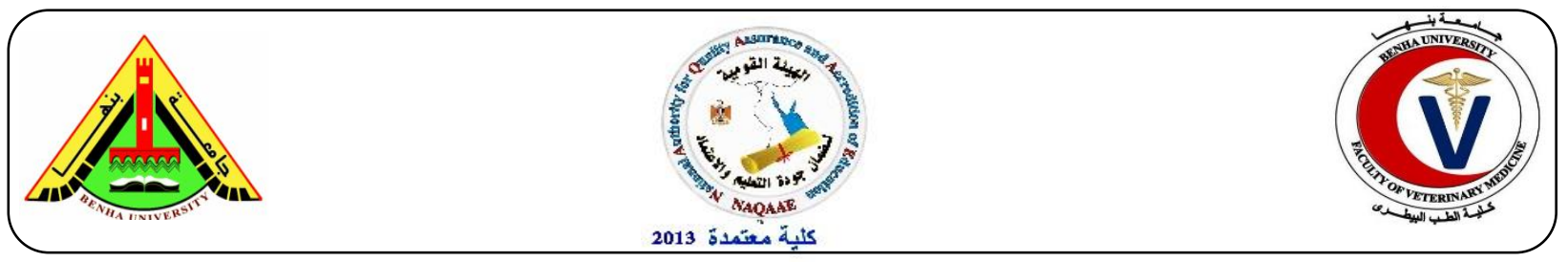

\title{
Phenotypic and genotypic characterization of listeria species isolated from chicken and milk products \\ ${ }^{1}$ Ashraf,A.Abd El Tawab, ${ }^{2}$ Wafaa, M.M Hassan, ${ }^{3}$ Fatma, I.El- Hofy, ${ }^{4}$ Haidy,T.Zaki \\ ${ }^{1}$ Bacteriology,Immunology and Mycology Dep., Fac.Vet.Med.Benha Univ. ${ }^{2}$ Animal Health Research
}

\begin{abstract}
Listeria monocytogenes has became increasingly important as a food-associated pathogen. It can cause a rare but serious disease called listeriosis with high fatality rates (20-30\%) compared with other foodborne microbial pathogens. To estimate the incidence and levels of Listeria spp. in different food sources, A total of 200 random samples which collected from different sources 65 samples isolated from poultry , 45 from poultry byproducts (Frozen chicken meat balls (kofta), Frozen chicken burger and frozen chicken sausages), 20 from pasteurized milk ,30 from milk products (Feta cheese ,cream cheese )and 40 from poultry eggs .Only 7(14\%) of samples that collected from suspected isolates and detected on Oxford agar, PALCAM agar and ALOA agar were suspected to be Listeria spp. In poultry, poultry byproducts, pasteurized milk, milk byproducts and poultry eggs, listeria percentage were 0/65(0\%), 4/45(1.8), 0/20(0\%), 0/30(0\%) , $3 / 40(1.2 \%)$ isolates, respectively. The in-vitro antimicrobial sensitivity test showed that the isolated L.monocytogenes were sensitive to Sulphamethoxazole /trimethoprim, Gentamycin ,Ceftazidime and Cephazoline followed by Sulphamethoxazole, ceftriaxone, weak sensitivity to Penicillin . While they were resistant to Erythromycin, Clindamycin, Ampicillin. The results of virulence tests for isolated listeria strains appeared that all of L.monocytogenes were virulent strains as all of them were positive to CAMP test; showed narrow zone of $\beta$-hemolysis on sheep blood agar .The PCR results for Listeria isolates showed that all strains are L.monoctogenes and have Inl $\mathrm{A}$ and $h l y$ A genes positive as virulence genes while negative $\operatorname{Inl} \mathrm{B}$, iap and prf A genes.
\end{abstract}

Keywords: L.monocytogenes, poultry, milk.

(http://www.bvmj.bu.edu.eg) (bvmj, 34(1): $94-105$, MARCH, 2018

\section{INTRODUCTION}

Veterinarians, medical doctors and people involved in food science know listeriosis by various names (circling disease, meningioencephalitis disease ,cheese sickness) but few know who Gustav Hülphers was because he did not preserve his bacterial strains, which he named bacillus hepatis, later recognized as Listeria monocytogenes (McLauchlin, 2004\& Hülphers, 2004).
Listeria monocytogenes is a Grampositive rod-shaped non-capsulated bacterium that form single short chains (Theivagt et al., 2006), facultative anaerobic, non-sporeforming, rod-shaped bacteria $0.5 \mathrm{~mm}$ in width and $1-1.5 \mathrm{~mm}$ in length (Vazquez-Boland et al., 2001 and Vera et al., 2013).

Taxonomically, it is divided into six species (i.e. Listeria monocytogenes, Listeria ivanovii, Listeria seeligeri, Listeria innocua, 
Listeria welshimeri and Listeria grayi), of which only L. monocytogenes and L. ivanovii are pathogenic. While L. monocytogenes infects both man and animals, L. ivanovii is principally an animal pathogen that rarely occurs in man. (Robinson et al., 2000).

The organism can survive at varying temperatures ranging from 4 to $37 \mathrm{C}$ (Janakiraman, 2008). The bacterium can tolerate a wide range of $\mathrm{pH}$ and temperatures. Optimum growth occurs at $30-37 \mathrm{C}$ but the organism can multiply at4-45C. A typical tumbling motility is observed around25C. It can grow at $\mathrm{pH} 4.5-9.6$, although the growth is minimal at low $\mathrm{pH}$ and low temperatures (OIE, 2014).

Listeriosis is often noticed along with other poultry diseases such as coccidiosis ,infectious coryza, verotoxic E.Coli ,salmonellosis, campylobacteriosis and parasitic infections ,signifying the opportunistic nature of the organism (Adzitey et al.,2012)

Egg and egg products have never been caused listeriosis but is most frequently isolated from egg shells and in the environment of laying hens.(Chemaly et al., 2008) L. monocytogenes can Survive 90 days on stored egg at $5 \mathrm{C}$ and for 15 days at $10 \mathrm{C}$ (Gandhi and chikindas, 2007 ).

Briefly, Invasiveness by virulence factors, L.monocytogenes expresses cellsurface and secreted proteins that enable attachment to host cells, escape from the phagocytic vacuole by Internalin A (inIA) and Internalin B (inIB) mediate the attachment of L. monocytogenes to the surface of host cells. Once ingested the bacterium produces listeriolysin (LLO) to escape from the phagosome and lyses the phagosomal membrane,The bacterium then multiply rapidly in the cytoplasm and moves through the cytoplasm to invade adjacent cells by polymerizing actin to form long tails ,the actin-assembly-inducing protein (ActA) which propels bacteria through the cell and into neighbouring cells, (Todar ,2008)

Each step requires expression of specific virulence factors. The major virulence genes are clustered together on the chromosomes and regulated by the positive regulatory factor A protein.PrfA (Positive Regulatory Factor A (PrfA). (Scortti et al.,2007 and Freitag et al.,2009).

There is interplay between temperature and L.monocytogenes motility. $L$. monocytogenes can employ either multiflagellar based motility or actin based propulsion depending on its environment. When L. Monocytogenes lives outside a host $\left(<30{ }^{\circ} \mathrm{C}\right)$, it is flagellated and utilizes these flagella for movement. When the bacteria encounters higher temperatures, like those in a host, the flagellar expression is halted and the bacteria are non-flagellated (Williams et al., 2005).

The present study was conducted to estimate the prevalence of listeria species in poultry and milk products with special interest to L.monocytogenes. In addition to clarify the virulence of isolated strains and to carry out the antibiotics sensitivity testing of them . In addition ,detection of some virulence factors of L.monocytogenes by PCR technique.

\section{MATERIAL AND METHODS}

\subsection{Samples collection:}

Two hundred random samples which collected from different sources 65samples isolated from poultry , 45 from poultry byproducts (Frozen chicken meat balls (kofta),Frozen chicken burger and frozen chicken sausages),20 from pasteurized milk ,30 from milk products (Feta cheese ,cream cheese) and 40 from poultry eggs. The samples were collected in sterile plastic bags, 
kept in ice box and transferred with a minimum delay to the laboratory for studying the presence of listeria species.

\subsection{Bacteriological examination:}

A-Primary stage: One $\mathrm{ml}$ of sample was inocluted into $9 \mathrm{ml}$ fraser broth 1, half fraser broth (without supplement) and incubated aerobically at $30 \pm 1$ c for $24 \pm 3$ hours .B-Secondary stage : one $\mathrm{ml}$ of incubated broth was inoculated into $9 \mathrm{ml}$ fraser broth 2 , full strength fraser broth (with supplement) and incubated at $37 \mathrm{C}$ for $48 \pm 3$ hours .CThird stage $: 0.1 \mathrm{ml}$ of incubated fraser broth was streaked onto the following media : ALOA agar; PALCAM agar and Oxford agar plates then the plates were incubated at $37 \pm 1$ Cfor 48 hours and examined after $24 \pm 3$ hours. The listeria like colonies were picked and streaked onto Tryptic Soy agar ( Bio-life ) with $0.6 \%$ yeast extract (TSA,YA) then, incubated at $35 \mathrm{C}$ for 48 hours. The isolates were morphologically identified by Gram stain and biochemical tests according to (Markey et al.,2013)

\subsection{In-Vitro anti-microbial sensitivity tests :}

The isolated L.monocytogenes strains were subjected to the sensitivity test against different antibiotics, using the disc and agar diffusion method: antibiotic discs are Erythromycin(E), Penicillin (P), Sulphamethoxazole (SM), ceftriaxone (CRO), Gentamycin (CN), Clindamycin (DA), Ampicillin (AM), Cefazoline (KZ), Sulphamethoxazole/ trimethoprime (SXT), ceftazidime (CAZ). (Finegold and Martin, 1982 and NCClS, 1999)

\subsection{Virulence tests :}

Hemolytic activity: all isolates were cultured on 5\% sheep blood agar to determine their hemolytic activity. Also, they were subjected to CAMP test (Mckellar,1994) by streaking staphylococcus aureus strains in single straight lines in parallel on sheep blood agar plates, the isolated listeria strains streaks perpendicularly,(1-2mm).then incubated for 24-48hours at 35C ,enhanced zone of $\beta$ hemolysis considered as a positive reaction.

\subsection{Genotypic detection of isolated} L.monocytogenes and some virulence in them using polymerase chain reaction ( $P C R)$

PCR using six sets of primers was used for genotypic detection of L.monocytogenes strains and five virulence genes of L.monocytogenes. The virulence genes were 16SRNA;internalin A (inlA); internalin B (inlB); heamolysin(hlyA) ;invasion associated protein (iap) and positive regulatory factor A (prfA).

It was applied on seven isolated L.monocytogenes following QIAamp® DNA Mini Kit instructions (Catalogue no. 51304),Emerald Amp GT PCR master mix (Takara) Code No. RR310A and Agarose 1\% (Sambrook et al., 1989). The PCR condition have specific sequence and amplify specific products as shown in Table (2). Temperature and time condition of the primers during PCR are shown in table (3) according to specific authors and Emerald Amp GT PCR master mix (Takara) kit.

\section{RESULTS}

Of the total 200 different samples analyzed,L. monocytogenes was detected in 7 samples with prevalence of $14 \%$; represented as in poultry, poultry byproducts, pasteurized milk, milk byproducts and poultry eggs, listeria percentage were $0 / 65(0 \%), 4 / 45(1.8)$, $0 / 20(0 \%), 0 / 30(0 \%), 3 / 40(1.2 \%)$ isolates, respectively. as Table (1) The isolated colonies grow well on ALOA agar producing blue-green colonies surrounded by opaque halo and on PALCAM agar gives grey-green with black center and black halo against cherry-red background and on Oxford agar gives grayish colonies surrounded by black halos. They were Gram - positive bacilli or coccobacilli ;motile showing Umbrella shaped motility. On biochemical reactions ,they produce acid from L-rhamnose, dextrose and but not with D-xylose and mannitol. The 
results of virulence tests showed that, all isolated L.monocytogenes strains showed narrow zone of $\beta$-hemolysis on $5 \%$ sheep blood agar, positive in CAMP test and showed as arrow-shaped zone of weak

were sensitive to Sulphamethoxazole / trimethoprim (100\%), followed by Gentamycin, Ceftazidime and Cephazoline (71.4\%), followed by Sulphamethoxazole, enhanced hemolysis at junction of tested strains and S. aureus strain. The result of in vitro sensitivity test showed that the isolated L.monocytogenes

ceftriaxone (42.8\%), weak sensitivity to Penicillin (14.2\%). While the isolated strains were resistant to Erythromycin, Ampicillin and Clindamycin as Fig (1)

Table (1): Total number and percentage of positive samples for listeria isolation from examined samples.

\begin{tabular}{|c|c|c|c|c|c|}
\hline & & & \multicolumn{3}{|c|}{ Positive percentage } \\
\hline Samples & $\begin{array}{c}\text { Number of } \\
\text { samples }\end{array}$ & $\begin{array}{c}\text { Number of } \\
\text { positive } \\
\text { samples }\end{array}$ & $\% 1$ & $\% 2$ & $\% 3$ \\
\hline Poultry & 65 & zero & zero & zero & zero \\
\hline Frozen wings & 35 & zero & zero & zero & zero \\
\hline Frozen breast & 30 & zero & zero & zero & zero \\
\hline Poultry products & 45 & 4 & 8.9 & 57.1 & 2.0 \\
\hline $\begin{array}{l}\text { Frozen chicken meat } \\
\text { balls (kofta) }\end{array}$ & 10 & 2 & 4.4 & 28.5 & 1.0 \\
\hline Frozen chicken burge & 15 & 1 & 2.2 & 14.2 & 0.5 \\
\hline frozen chicken sausages & 20 & 1 & 2.2 & 14.2 & 0.5 \\
\hline Pasteurized Milk & 20 & zero & zero & zero & zero \\
\hline Milk products & 30 & zero & zero & zero & zero \\
\hline Feta cheese & 10 & zero & zero & zero & zero \\
\hline Cream cheese & 20 & zero & zero & zero & zero \\
\hline Poutry eggs & 40 & 3 & 7.5 & 42.8 & 2.5 \\
\hline Total & 200 & 7 & 3.5 & 100.0 & 3.5 \\
\hline
\end{tabular}

\footnotetext{
${ }^{1}$ Percentage in relation to total number of samples in each raw.

${ }^{2}$ Percentage in relation to total number of positive samples (7).

${ }^{3}$ Percentage in relation to total number of collected samples(200).
} 


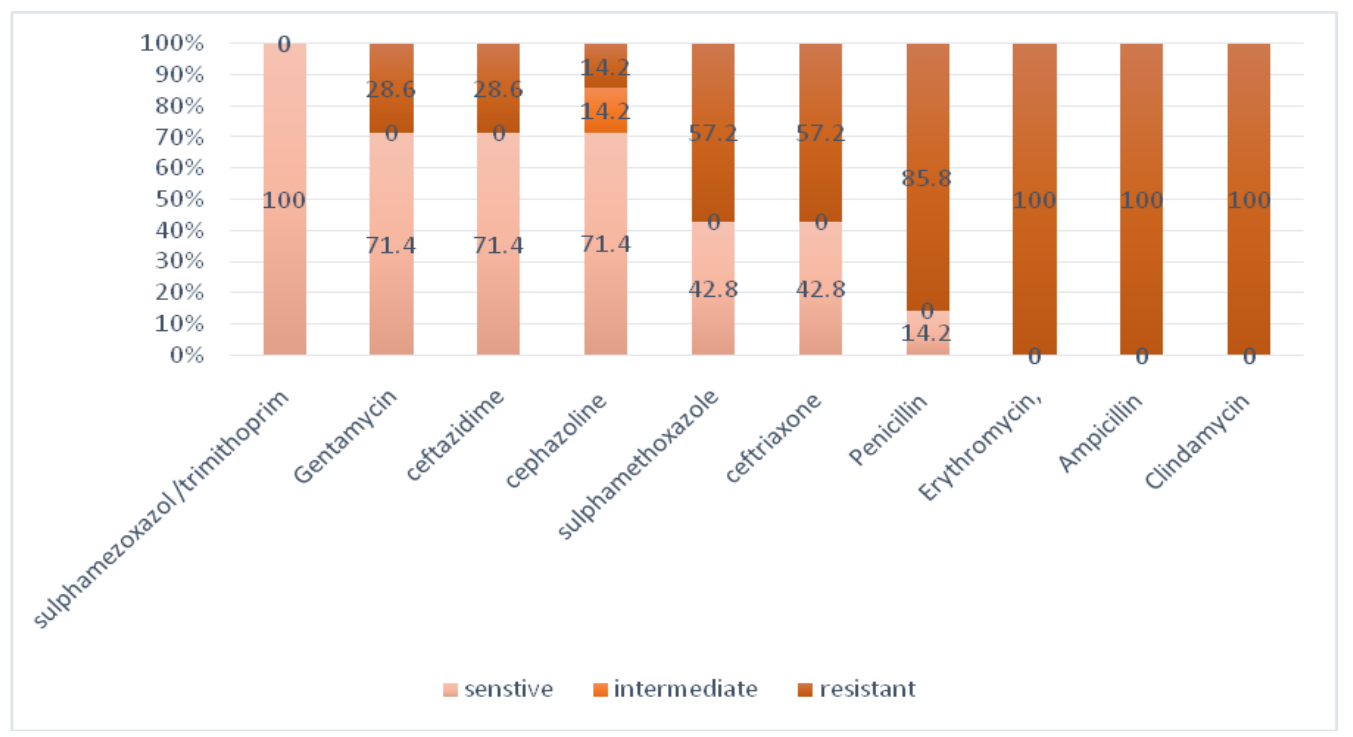

Fig.(1): In-vitro antimicrobial sensitivity test for isolated L.monocytogenes .

Table (2): Oligonucleotide primers sequences sources

\begin{tabular}{|c|c|c|c|}
\hline Primer & Sequence & $\begin{array}{l}\text { Amplifie } \\
\text { d product }\end{array}$ & Reference \\
\hline $16 S$ rRNA & $\begin{array}{l}\text { ggA CCg ggg CTA ATA CCg AAT gAT AA } \\
\text { TTC ATg TAg gCg AgT TgC AgC CTA }\end{array}$ & 1200 bp & $\begin{array}{l}\text { Kumar et } \\
\text { al., } 2015\end{array}$ \\
\hline Iap & $\begin{array}{c}\text { CTG CTT GAG CGT TCA TGT CTC ATC } \\
\text { CCC C } \\
\text { CAT GGG TTT CAC TCT CCT TCT AC }\end{array}$ & $131 \mathrm{bp}$ & $\begin{array}{l}\text { Soni et al., } \\
2014\end{array}$ \\
\hline prfA & $\begin{array}{l}\text { TCT-CCG-AGC-AAC-CTC-GGA-ACC } \\
\text { TGG-ATT-GAC-AAA-ATG-GAA-CA }\end{array}$ & 1052 bp & $\begin{array}{l}\text { Dickinson } \\
\text { et al., } 1995\end{array}$ \\
\hline inlA & $\begin{array}{l}\text { ACG AGT AAC GGG ACA AAT GC } \\
\text { CCC GAC AGT GGT GCT AGA TT }\end{array}$ & $800 \mathrm{bp}$ & Liu et al., \\
\hline inlB & $\begin{array}{l}\text { Ctggaaagtttgtatttgggaaa } \\
\text { tttcataatcgccatcatcact }\end{array}$ & $343 \mathrm{bp}$ & 2007 \\
\hline hlyA & $\begin{array}{l}\text { GCA-TCT-GCA-TTC-AAT-AAA-GA } \\
\text { TGT-CAC-TGC-ATC-TCC-GTG-GT } \\
\text { CCYTTTTATGTACCCAYGA }\end{array}$ & 174 bp & $\begin{array}{c}\text { Deneer and } \\
\text { Boychuk, } \\
1991\end{array}$ \\
\hline
\end{tabular}


Table (3): cycling conditions of the different primers during cPCR

\begin{tabular}{ccccccc}
\hline Gene & $\begin{array}{c}\text { Primary } \\
\text { denaturation }\end{array}$ & $\begin{array}{c}\text { Secondary } \\
\text { denaturation }\end{array}$ & Annealing & Extension & $\begin{array}{c}\text { No. of } \\
\text { cycles }\end{array}$ & $\begin{array}{c}\text { Final } \\
\text { extension }\end{array}$ \\
\hline l6S & $94^{\circ} \mathrm{C}$ & $94^{\circ} \mathrm{C}$ & $60^{\circ} \mathrm{C}$ & $72^{\circ} \mathrm{C}$ & 35 & $72^{\circ} \mathrm{C}$ \\
$r R N A$ & $5 \mathrm{~min}$. & $30 \mathrm{sec}$. & $1 \mathrm{~min}$. & $1 \mathrm{~min}$. & & $12 \mathrm{~min}$. \\
Iap & $94^{\circ} \mathrm{C}$ & $94^{\circ} \mathrm{C}$ & $60^{\circ} \mathrm{C}$ & $72^{\circ} \mathrm{C}$ & 35 & $72^{\circ} \mathrm{C}$ \\
& $5 \mathrm{~min}$. & $30 \mathrm{sec}$. & $30 \mathrm{sec}$. & $30 \mathrm{sec}$. & & $7 \mathrm{~min}$. \\
prfA & $94^{\circ} \mathrm{C}$ & $94^{\circ} \mathrm{C}$ & $50^{\circ} \mathrm{C}$ & $72^{\circ} \mathrm{C}$ & 35 & $72^{\circ} \mathrm{C}$ \\
& $5 \mathrm{~min}$. & $30 \mathrm{sec}$. & $50 \mathrm{sec}$. & $1 \mathrm{~min}$. & & $10 \mathrm{~min}$. \\
inlA & $94^{\circ} \mathrm{C}$ & $94^{\circ} \mathrm{C}$ & $55^{\circ} \mathrm{C}$ & $72^{\circ} \mathrm{C}$ & 35 & $72^{\circ} \mathrm{C}$ \\
& $5 \mathrm{~min}$. & $30 \mathrm{sec}$. & $45 \mathrm{sec}$. & $45 \mathrm{sec}$. & & $10 \mathrm{~min}$. \\
inlB & $94^{\circ} \mathrm{C}$ & $94^{\circ} \mathrm{C}$ & $55^{\circ} \mathrm{C}$ & $72^{\circ} \mathrm{C}$ & 35 & $72^{\circ} \mathrm{C}$ \\
& $5 \mathrm{~min}$. & $30 \mathrm{sec}$. & $40 \mathrm{sec}$. & $40 \mathrm{sec}$. & & $10 \mathrm{~min}$. \\
hlyA & $94^{\circ} \mathrm{C}$ & $94^{\circ} \mathrm{C}$ & $50^{\circ} \mathrm{C}$ & $72^{\circ} \mathrm{C}$ & 35 & $72^{\circ} \mathrm{C}$ \\
& $5 \mathrm{~min}$. & $30 \mathrm{sec}$. & $30 \mathrm{sec}$. & $30 \mathrm{sec}$. & & $7 \mathrm{~min}$. \\
\hline
\end{tabular}

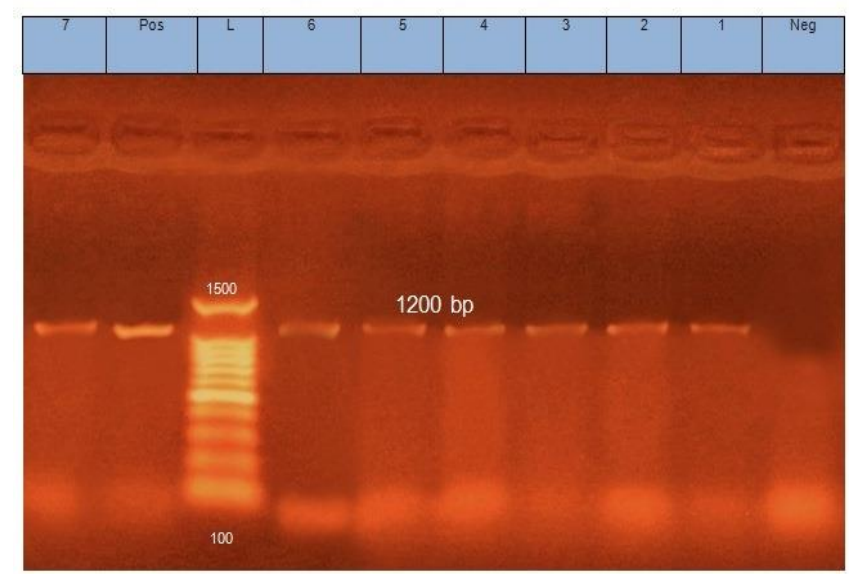

Fig. (2): 16SrRNA genes . Lane L:100-1500bp Ladder. Neg:Negative control . Pos. :positive control at (1200bp) .Lanes 1 to 7 :L.monocytogenes (16SrRNA) gene positive

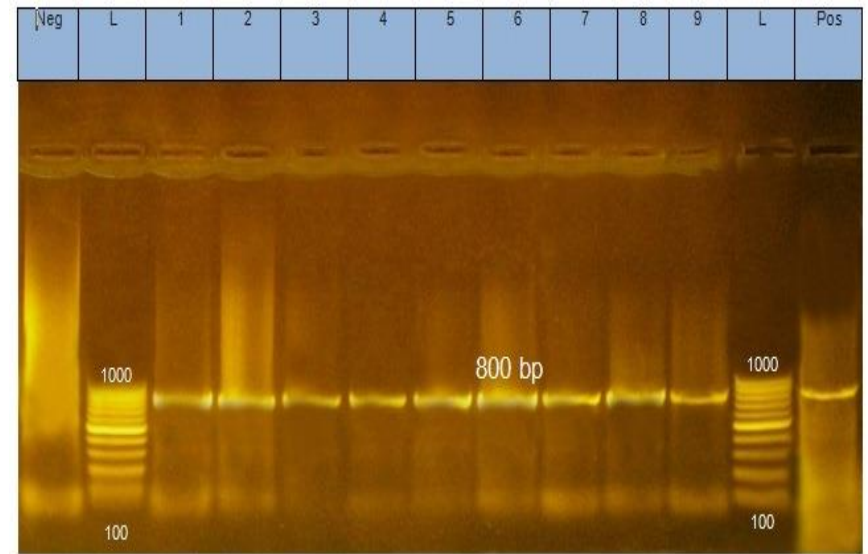

Fig.(3): inlA gene. Lane L:100-1000bp Ladder. Neg:Negative control . Pos:Positive control at (800bp ). Lanes 1 to 7 :L.monocytogenes (inlA )gene positive. 

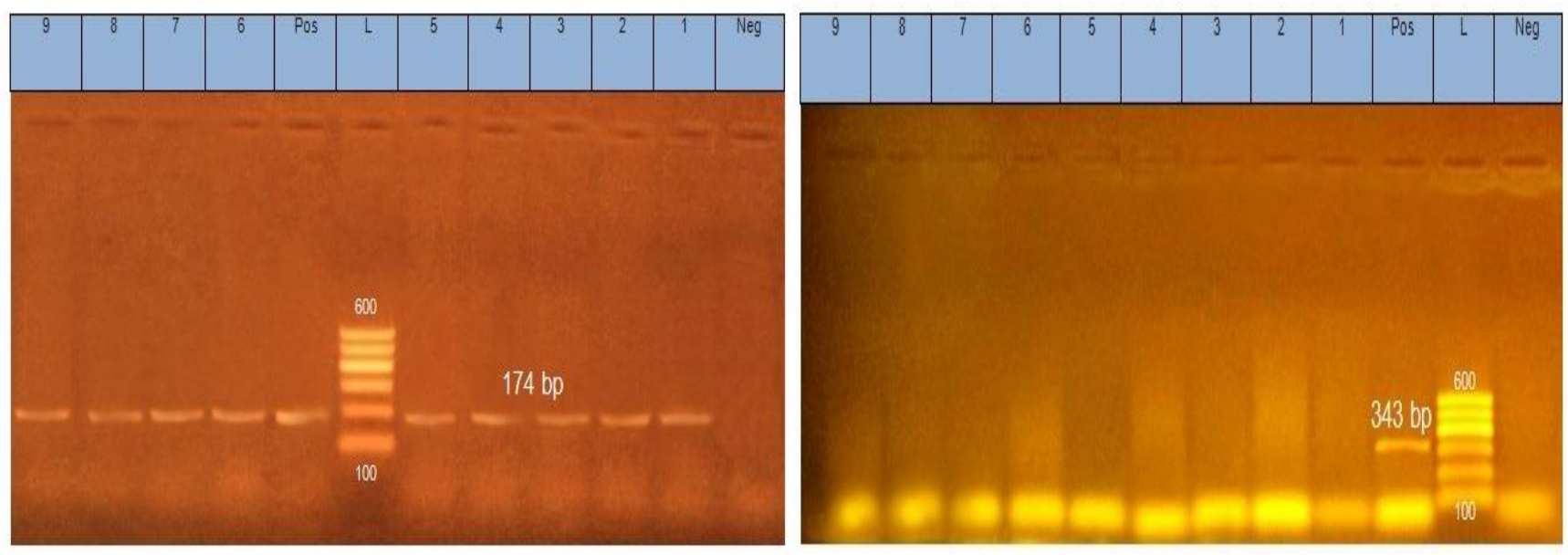

Fig.(4): hlyA gene. Lane L:100-600bp Ladder. Neg: Negative control . Pos:Positive control at (174bp ). Lanes 1 to 7 :L.monocytogenes (hlyA )gene positive.

Fig. (5): inlB gene. Lane L:100-600bp Ladder. Neg: Negative control . Pos:Positive control at (343bp). Lanes 1 to $7:$ :.monocytogenes (inlB) gene negative
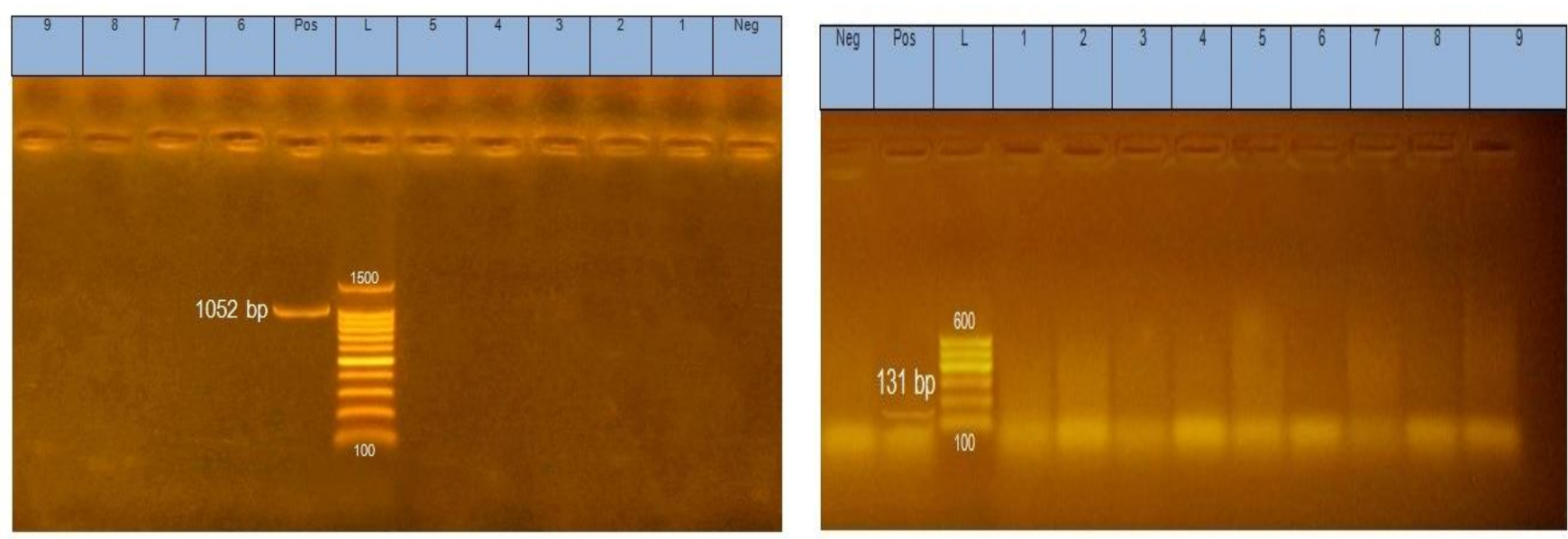

Fig.(6): prfA gene. Lane L:100-1500bp Ladder. Neg: Negative Fig.(7): iap gene. Lane L:100-600bp Ladder. Neg: control . Pos:Positive control at (1052bp ). Lanes 1 to 7 :L.monocytogenes (prfA )gene negative

\section{DISCUSSION}

Most human listeriosis cases appear to be linked to consumption of ready-to-eat (RTE) food products (Lunde'n et al., 2004). In particular, L. monocytogenes Negative control . Pos:Positive control at (131bp ). Lanes 1 to 7 :L.monocytogenes (iap)gene negative

contamination of fermented dairy products made from raw milk may be due either to use of contaminated raw milk or to postprocessing contamination from 
environmental sources not directly linked to raw milk (Kells and Gilmour, 2004).

Listeriosis is of great public health concern because of its high mortality (20 to $30 \%$ ) and its common source epidemic potential. The most important aspect in food hygiene is the ability of the bacteria to survive in a wide range of temperatures and to make biofilms on various environmental surfaces, which serve as natural habitats or reservoirs (Duggan and Phillips, 1998).

Listeriosis is caused by members of the genus Listeria, which has now 17 species. However, only two species are considered pathogenic.

L. monocytogenes is considered pathogenic to human beings and several animal species, whereas $L$. ivanovii is pathogenic especially to ruminants but occasionally to humans (McLauchlin\& Martin, 2008).

Ability of L. monocytogenes to cause disease depends upon the expression of virulence factors and immune status of individuals. Usually individuals having weakened cell-mediated immunity are more susceptible to L. monocytogenes. (Lecuit et al., 2004)

The result of isolated samples as in Table (1) revealed that $L$. monocytogenes was detected in 7 samples out of 200 samples (14\%)represented as in poultry, poultry byproducts, pasteurized milk, milk byproducts and poultry eggs, listeria percentage were $0 / 65(0 \%), 4 / 45(1.8)$, $0 / 20(0 \%), 0 / 30(0 \%), 3 / 40(1.2 \%) \quad$ isolates, respectively that disagreed with that recorded by (Alsheikh et al.,2013 and Zeinali et al., 2017)

In this research listeria monocytogenes was found in Frozen wings of poultry, frozen breast of poultry by percentage $(0 \%)$ that totally disagreed with (Reiter et al., 2005)

The result of in vitro sensitivity test showed that ,the isolated L.monocytogenes were highly sensitive to Sulphamethoxazole /trimethoprim (100\%), followed by Gentamycin Ceftazidime and Cephazoline (71.4\%), followed by Sulphamethoxazole, ceftriaxone $(42.8 \%)$, weak sensitivity to Penicillin (14.2\%). While the isolated strains were resistant to Erythromycin, Ampicillin and Clindamycin. And these results came in accordance with those recorded by (Zeinali et al., 2017) and disagreed with (Hof, 2004; Altuntas et al.,2012).

The heamolytic activities of listeria species determine its pathogenicity (Maarouf et al., 2007). The result of virulence tests for isolated listeria showed that ,all L.monocytogenes were positive to CAMP test and showed narrow zone of $\beta$-heamolysis in sheep agar, the similar results were reported by (Boland et al., 2001 and Marrouf et al ., 2007)

The PCR results for L.monocytogenes isolated showed that $(16 \operatorname{SrRNA}$;inl $A$ and hly $A)$ genes were detected in all seven strains. While inl B; iap and perfA genes are not detected in all isolated that dissimilar to that reported by (Xiaolong et al., 2017)

Regarding to the occurance of 16SrRNA genes in L.monocytogenes isolates, the obtained result revealed that, it was amplified in all seven tested isolates $100 \%$ ,that agreed with those recorded by (Gelbicova and Karpiskova ,2012 and Ciolacu et al .,2015)

The result of PCR for amplification of internalin A (inlA) gene in L.monocytogenes (Fig.3) showed that, inlA gene was amplified in all seven tested isolates giving product of 800bp, that similar recorded by (Gelbicova 
and Karpiskova ,2012 and Ciolacu et al .2015).

The result of PCR for amplification of internalin B (inlB)gene in L.monocytogenes (Fig.5) showed that, inlB gene wasn't amplified in all seven tested isolates, that disagreed with (Shen et al., 2000)

The result of PCR for amplification of listeriolysin $\mathrm{O}$ (heamolysin,hlyA) gene in L.monocytogenes (Fig.4) showed that, hlyA gene was amplified in all seven tested isolates giving product of $174 \mathrm{bp}$, that similar recorded by (Schuerch et al., 2005; Gelbicova and Karpiskova ,2012; Khan et al., 2014; and Ciolacu et al .,2015).

The result of PCR for amplification of positive regulatory factor gene (prfA) in L.monocytogenes (Fig6) showed that, prfA gene wasn't amplified in all seven tested isolates, that dissimilar with (Holko et al., 2002; Gelbicova and Karpiskova ,2012and Ciolacu et al .,2015).

The result of PCR for amplification of Invasion-associated protein (iap) gene in L.monocytogenes (Fig7) showed that iap gene wasn't amplified in all seven tested isolates, that dissimilar with (Schuerch et al., 2005).

At the last, we can conclude from the present work that L.monocytogenes are mainly food born pathogen that could contaminate poultry products ,milk ,milk products and poultry eggs causing listeriosis. The isolated L.monocytogenes were sensitive to Sulphamethoxazole / trimethoprim (100\%), followed by Gentamycin, Ceftazidime and Cephazoline $(71.4 \%)$, and resistant to Erythromycin, Ampicillin and Clindamycin.all the isolated L.monocytogenes were CAMP Positive and produce $\beta$-zone of heamolysis .In PCR result assured that all seven strains are listeria monocytogenes and have InlA and hlyA virulence genes and lack inlB, prfA and iap genes.

\section{REFERENCES}

Adzitey, F., N.,Huda and G.R. Rahmat Ali,2012. Prevalence and antibiotic resistance of Campylobacter ,Salmonella and L. monocytogenes in ducks:A review . Foodborne Pathog.Dis, 9:498-505.

Alsheikh A. D. I., Mohammed G. E. and Abdulla M.A. (2013). Isolation and Identification of Listeriamonocytogenes from Retail Broiler Chicken Ready to Eat Meat Products in Sudan, International Journal of Animal and Veterinary Advances 5(1): 9-14

Altuntas EG, Kocan D, Cosansu E, Ayhan K, JunejaVK,

Materon2012

L.monocytogenes Antibiotic and bacteriocin sensitivity of Listeria monocytogenes strains isolated from different foods. JFNS. 2012 Mar;3(3):363-8. DOI: 10.4236/fns.2012.33052

Chemaly ,M.,M.T. Toquin, Y. Le Notre and P. Fravalo,2008. Prevalence of Listeria monocytogenes in poultry production in France. J.Foot ., 71:1996-2000.

Ciolacu, L.,nicolau, A.I., Wagner, m., Rychli ,K., 2015 .Listeria monocytogenes isolated from food samples from a Romanian Black market show distinct virulence profiles . Int . J. Food Microbial., 209:44-51

Deneer, H.G. and BOYCHUK, I. (1991): Species-Specific Detection of Listeria monocytogenes by DNA Amplification. APPLIED AND ENVIRONMENTAL MICROBIOLOGY, Feb. 1991, p. 606609.

Dickinson, J.H.; Kroll, R.G. and Grant, K.A. (1995): The direct application of the polymerase chain reaction to DNA extracted from foods. Letters in 
Applied Microbiology 1995, 20, 212216.

Duggan., J., Phillips., C.A. (1998). Listeria in the domestic environment. Nutrition \& Food Science. 98, 73-79.

Finegold, S.M., Martin, W.J.1982.Bailley and Scott Diagnostic Microbiology $6^{\text {th }}$ ed., C.V. Mosby Co. St. Louis. Toronto, London.

Freitag NE, Port GC, Miner MD:Listeria monocytogenes - from saprophyte to intracellular pathogen. Nat Rev Microbiol 2009, 7:623-628.

Gandhi, M. and M.L.Chikindas,2007.Listeria :A foodborne pathogen that knows how to survive Int.J.Food Microbial., 113:1-15.

Gelbicova,T., Karpiskova, R. 2012. Outdoor environment as a source of L.monocytogenes in food chain Czech J .Food Sci.30(1):83-88.

Hof H. An update on the medical management of listeriosis. Expert. Opin. Pharmacother. (2004);5:17271735. doi: $10.1517 / 14656566.5 .8 .1727$

Holko,I.,Urbanova, J., Kantikova , M., Pastorova, K., Kmee, V.2002. PCR Detection of Listeria monocytogenesin milk and milk products and diffentiation of suspect Isolates .ACTA VET.BRNO(71):125-131.

Janakiraman V. 2008. Listeriosis in pregnancy: diagnosis, treatment, and prevention. Rev Obstet Gynecol. 1:179-185.

Jaradat ZW, Schutze GE, Bhunia AK: Genetic homogeneity among Listeria monocytogenes strains from infected patients and meat products from two geographic locations determined by phenotyping, ribotyping and $P C R$ analysis of virulence genes. Int J Food
Microbiol. 2002, 76: 1-10. 10.1016/S0168-1605(02)00050-8.

Kells, S., and A. Gilmour. 2004. Incidence of Listeria monocytogenes in two milk processing environments and assessment of Listeria monocytogenes blood agar for isolation. Int. J. Food Microbiol. 91:167-174.

Khan, J.A., Rathore, R.S., Khan, S., Ahmad, I.2014.In vitro detection of pathogenic listeria monocytogenes from food sources by conventional, molecular and cell culture method. Braz.J. Microbial., 44(3):751-759

Kumar, A.; Grover, S. and Batish, V.K. (2015): Exploring specific primers targeted against different genes for a multiplex PCR for detection of Listeria monocytogenes. 3 Biotech (2015) 5:261-269.

Lecuit, M., Nelson, D.M., Smith, S.D., Khun, H., Huerre, M., Vacher-Lavenu, M.C., Gordon, J.I., Cossart, P. (2004). Targeting and crossing of the human maternofetal barrier by Listeria monocytogenes: role of internalin interaction with trophoblast Ecadherin. ProcNatlAcadSci U S A 101, 6152-6157.

Lunde'n, J., R. Tolvanen, and H. Korkeala. 2004. Human listeriosis outbreaks linked to dairy products in Europe. $\mathrm{J}$. Dairy Sci. 87. (E Suppl.):E6-E11.

Markey, B.K., Leonard,F.C., Archambault, M., Cullinane,A., Maguire, D.2013. Clinical Veterinary Microbiology. Second edition .Mosby.ElsevierLtd.Edinburgh London New York Oxford Philadelphia St Louis Sydney Toronto .

Marrouf, A.A., El-Bealawy, M.A., Moubarak, M.G. 2007 . Some studies of listeriosis in sheep atEl-Kaliobia 
government.J.Egypt.Vet.Med.Assoc.67 (4):27-40.

Mateus T, Silva J, Maia RL, Teixeira P. 2013.Listeriosis during pregnancy: a public health concern. ISRN Obstet Gynecol. 2013:851712

McLauchlin J, Martin W. 2008. Biology. In: Liu D, editor. Handbook of Listeria monocytogenes. Boca Raton (FL): CRC Press; p. 4.

McLauchlin., J. (2004). Was Hulpers the first to describe Listeria monocytogenes. XV International Symposium on Problems of Listeriosis., 147b.

NCCLS.1999 .National Committee For Clinical Laboratory Standards. Performance Standards for Antimicrobial Disk and Dilution Susceptibility Tests for Bacteria isolated from animals .Approved Standard M31-A. NCCLS, Wayne,USA.

OIE. 2014. Listeria monocytogenes. Chapter 2.9.7. Manual ofdiagnostic tests and vaccines for terrestrial animals. p.1-18. Available from: http://www.oie.int/manual-of diagontic- tests-and- vaccines for terrestrial animals

Reiter,M.G.R; Camila B.M.M.; Carmen, L. and Jordano,R. (2005): Occurrence of Campylobacter and L.monocytogenes in a poultry Processing plant. J. food Prot.,68(9):1903-1906.

Robinson, R. K., Batt, C. A. \& Patel, P. D. (editors) (2000).Encyclopedia of Food Microbiology. San Diego, CA: Academic Press.

Sambrook, J.; Fritscgh, E.F.;andMentiates (1989): Molecular coloning. A laboratory manual. Vol !., Cold spring Harbor Laboratotry press, New York.

Schuerch, D.W.; Wilson-Kubalek, E.M.; Tweten, R.K. (2005). Molecular basis of listeriolysin $\mathrm{O} \mathrm{pH}$ dependence.
Proc. Natl. Acad. Sci. U.S.A. 102(35), 12537-12542.

Scortti M, Monzo HJ, Lacharme-Lora L, Lewis DA, Vazquez- Boland JA: The PrfA virulence regulon. Microbes Infect 2007, 9:1196-1207

Shen Y, Naujokas M, Park M, Ireton K (2000) InIB-dependent internalization of Listeria is mediated by the Met receptor tyrosine kinase. Cell 103: 501-510.

Soni, D.K.; Singh, M.; Singh, D.V. and Dubey, S.K. (2014): Virulence and genotypic characterization of Listeria monocytogenes isolated from vegetable and soil samples. BMC Microbiology, 14:241.

Theivagt, A.E., Friesen, J.A. (2006). "Purification and characterization of Listeria monocytogenes HMG-CoA reductase" FASEB Journal 20 (4, Part 1): A472 MAR 62006.

Todar, K. (2008):"Listeria monocytogenes". Todar's Online Textbook of Bacteriology. Retrieved January 28, 2009.

Vazquez-Boland, J. A., Kuhn, M., Berche, P., Chakraborty, T., Dominguez-Bernal, G., Goebel, W., Gonzalez Zorn, B., Wehlan, J. \&Kreft, J. (2001). Listeria pathogenesis and molecular virulence determinants. ClinMicrobiol Rev 14, 584-640.

Vera A, Gonzalez G, Domınguez M, Bello H. 2013. Main virulence factors of Listeria monocytogenes and its regulation.RevChilenaInfectol. 30:407416

Williams, T., B. Joseph, D. Beier, W. Goebel and M. Kuhn (2005). "Response regulator DegU ofListeria monocytogenes regulates the expression of flagella-specific genes." FEMS MicrobiolLett252(2): 287- 298 
Xiaolong Cao a,b, Yi Wang b,Yan Wang b,ChangyunY e b (2017) Isolation and characterization of Listeria monocytogenes from the black head gull feces in Kunming China Journal of and Public Health 11(2018)59-63

Zeinali, T., Jamshidi, A., Bassami, M. and 4Rad, M. (2017)Isolation and identification of Listeria spp. in chicken carcasses marketed in northeast of Iran.International Food Research Journal 24(2): 881-887 (April 2017) 